\title{
Efek Pemanasan Skala Rumah Tangga terhadap Komponen Bioaktif Daun Kenikir (Cosmos caudatus)
}

\author{
Effect of Household Scale Heating on Bioactive Compound Kenikir Leaves (Cosmos caudatus)
}

\author{
A. Ardiansyah ${ }^{1 *}$, Risqah Fadilah ${ }^{1}$, Dody Dwi Handoko ${ }^{2}$, Bram Kusbiantoro ${ }^{2}$, Rizki Maryam Astuti ${ }^{1}$ \\ ${ }^{1}$ Program Studi Ilmu dan Teknologi Pangan, Fakultas Teknik dan Ilmu Komputer, Universitas Bakrie, \\ Kawasan Epicentrum, JI. HR Rasuna Said, Kav C.22, Jakarta 12920, Indonesia \\ ${ }^{2}$ Balai Besar Penelitian Padi, Balai Penelitian dan Pengembangan Pertanian, Kementrian Pertanian, \\ Jl. Raya 9, Sukamandi, Subang, Jawa Barat 41256, Indonesia \\ *Email: ardiansyah@bakrie.ac.id
}

Tanggal submisi: 1 Maret 2019; Tanggal penerimaan: 13 Juni 2019

\begin{abstract}
ABSTRAK
Daun kenikir (Cosmos caudatus) merupakan salah satu jenis sayuran yang biasa dikonsumsi oleh masyarakat Indonesia baik dalam dalam keadaan segar atau dimasak. Penelitian ini bertujuan untuk mempelajari pengaruh pemanasan skala rumah tangga (perebusan, pengukusan, atau pemanasan dengan microwave) terhadap nilai total senyawa fenolik (TSF), aktivitas antioksidan, dan komponen bioaktif daun kenikir. Penelitian ini terbagi menjadi beberapa tahap yaitu persiapan sampel, proses pengolahan skala rumah tangga, ekstraksi, analisis kandungan TSF dengan metode folin-ciocalteu, analisis aktivitas antioksidan menggunakan metode DPPH, dan analisis komponen aktif (asam kafeat dan asam ferulat) menggunakan reversed phase-ultra high performance liquid chromatography. Kandungan TSF dari ekstrak daun kenikir segar adalah 148,29-262,36 mg/100 g BB. Pengolahan dengan cara perebusan atau pemanasan microwave selama 3 menit menurunkan secara nyata $(p<0,05)$ kandungan TSF dan aktivitas antioksidan daun kenikir, demikian halnya dengan kandungan asam kafeat dan asam ferulat. Sedangkan proses pengolahan dengan pengukusan atau pemanasan microwave selama satu menit tidak menunjukkan perbedaan nyata kandungan TSF dan aktivitas antioksidan bila dibandingkan dengan daun segar. Selanjutnya proses pengolahan dengan pengukusan atau pemanasan microwave selama satu menit dapat mempertahankan kandungan asam kafeat dan asam ferulat. Analisis korelasi menunjukkan bahwa terdapat korelasi positif antara kandungan TSF dan aktivitas antioksidan daun kenikir $(r=0,904)$.
\end{abstract}

Kata kunci: Antioksidan; daun kenikir; komponen bioaktif; pemanasan; total senyawa fenolik

\begin{abstract}
Kenikir leaves (Cosmos caudatus) are one type of vegetable that is commonly consumed in Indonesia both in fresh or cooked forms. The research was aimed to investigate the effect of household scale heating (boiling, steaming, or microwave heating) on the total phenolic content (TPC), antioxidant activity, and bioactive components of kenikir leaves. The research was divided into several stages such as sample preparation, household scale processing method, extraction, TPC analysis by folin-ciocalteu method, antioxidant activity analysis by DPPH method, and bioactive components analysis (caffeic acid and ferulic acid) by a reversed-phase ultra-high-performance liquid chromatography. The TPC of fresh kenikir leaves extract was $148.29-262.36 \mathrm{mg} / 100 \mathrm{~g}$ WB. Boiling or microwave heating for 3 minutes significantly decreased $(p<0.05)$ TPC and antioxidant activity of kenikir leaves, as well as caffeic acid and ferulic acid contents. The steaming or microwave heating for one minute didn't show significant
\end{abstract}




\begin{abstract}
differences in TPC and antioxidant activity when compared to fresh kenikir leaves. Furthermore, the steaming or microwave heating for one minute could maintain caffeine acid and ferulic acid contents of kenikir leaves. The correlation analysis showed that there was a positive correlation between TPC and antioxidant activity of kenikir leaves $(r=0.904)$.
\end{abstract}

Keywords: Antioxidant; bioactive compounds; heating; kenikir leaves; total phenolic content

\section{PENDAHULUAN}

Kenikir (Cosmos caudatus) adalah tanaman dalam kelompok famili Compositae. Tanaman ini merupakan tanaman yang umum dan populer dengan nama "ulam raja" dan sering dikonsumsi sebagai salad di Malaysia dengan cara dicelupkan ke dalam sambal cabai dan udang (Bodeker, 2009). Di Indonesia terutama masyarakat Sunda, daun kenikir banyak dikonsumsi sebagai lalap. Sedangkan pada masyarakat Jawa, kenikir biasanya ditambahkan sebagai pelengkap pada sayur pecel dengan direbus terlebih dahulu atau diseduh dengan air panas.

Daun kenikir segar memiliki kandungan total senyawa fenolik (TSF) $1,52 \pm 0,11 \mathrm{mg} \mathrm{GAE} / \mathrm{g}$ berat basah (BB) dan aktivitas antioksidan sebesar $112 \pm 3$ $\mu \mathrm{mol} \mathrm{TE} / \mathrm{g} \mathrm{BB}$, serta kandungan asam kafeat dan asam ferulat dengan kandungan masing-masing 3,64 mg/100 $\mathrm{g}$ dan 3,14 mg/100 g BB (Andarwulan dkk., 2010; Andarwulan dkk., 2012). Studi lain oleh Mustafa dkk. (2010) menyebutkan bahwa ekstrak metanol dari daun kenikir memiliki aktivitas antioksidan yang tinggi dengan nilai IC50 21,3 $\mu \mathrm{g} / \mathrm{mL}$. Kenikir memiliki banyak manfaat bagi kesehatan diantaranya memiliki aktivitas inflamasi karena kandungan flavonoid (Ajaykumar dkk., 2012), dapat meningkatkan sirkulasi darah dan memperkuat tulang (Bodeker, 2009), serta dapat meningkatkan selera makan (Andarwulan dkk., 2012).

Proses pemanasan seperti perebusan, pengukusan, dan penggorengan pada sayuran dapat menurunkan kandungan gizi dan kualitas komponen bioaktif (Miglio dkk., 2008). Hasil penelitian yang dilakukan oleh Girgin dan El (2015) menyatakan bahwa kol yang direbus dapat menurunkan kandungan TSF dan aktivitas antioksidan. Sun dkk. (2014), memperlihatkan bahwa terjadi penurunan kadar lemak setelah proses pemasakan (perebusan, pengukusan, microwave, dan pemanggangan) dibandingkan daun segar ubi jalar. Tetapi pada studi yang sama (Sun dkk., 2014) menunjukkan bahwa pemasakan dengan pengukusan dinilai paling baik untuk meminimalkan penurunan kandungan TSF dan dan aktivitas antioksidan.

Beberapa studi sebelumnya melaporkan bahwa pengaruh pemasakan rumah tangga terhadap beberapa jenis sayuran. Sampai saat ini belum ada penelitian yang mempelajari pengaruh pemasakan tingkat rumah tangga terhadap perubahan kandungan bahan aktif daun kenikir. Oleh karena itu, pada penelitian ini bertujuan untuk mengetahui pengaruh jenis pemanasan skala rumah tangga (perebusan, pengukusan, atau pemanasan dengan microwave) terhadap kandungan TSF, aktivitas antioksidan, dan kandungan bioaktif pada daun kenikir.

\section{METODE PENELITIAN}

\section{Bahan dan Alat}

Daun kenikir segar diperoleh dari pasar tradisional Citayam, Depok, Jawa Barat, metanol HPLC grade (Merck, Darmstadt, Jerman), reagen Folin-Ciocalteu (Merck, Darmstadt, Jerman), reagen 2,2-diphenyl-1picryhydrazyl (DPPH) (Sigma-Aldrich, St. Louis, Amerika Serikat), Na2CO3 (Merck, Darmstadt, Jerman), standar asam galat (Sigma-Aldrich, St. Louis, Amerika Serikat), standar asam askorbat (Merck, Darmstadt, Jerman), serta standar asam kafeat dan standar asam ferulat (Sigma-Aldrich, St. Louis, Amerika Serikat).

Alat-alat yang digunakan adalah microwave oven (LG tipe MS2342D, Cikarang, Indonesia), waterbath (Barnstead International 18002A-ICE, Dubuque, Amerika Serikat), sonikator (Elmasonic S $180 \mathrm{H}, \mathrm{f}$ $50 / 60 \mathrm{~Hz}$, Singen, Jerman), centrifuge (Beckman Coulter Allegra $64 \mathrm{R}$ and Avanti, Breal, California, Amerika Serikat), spektrofotometer UV VIS (UV-2550 Shimadzu, Kyoto, Japan) dan Reverse Phase-Ultra High Performance Liquid Chromatography (UHPLC) Perkin Elmer tipe Flexar FX (Perkin Elmer, Amerika Serikat).

\section{Persiapan Sampel}

Daun kenikir sebelum digunakan dibersihkan dengan air kran, dikeringkan dengan angin, kemudian dibagi empat perlakuan pemasakan. Daun kenikir yang digunakan sebanyak 6,25 gram dengan jumlah daun pucuk dan daun pada bagian tengah yang sama pada setiap perlakuan. 


\section{Metode Pemanasan}

Metode pemanasan yang dilakukan dalam penelitian ini berdasarkan penelitian yang dilakukan oleh Sun dkk. (2014) dengan perlakuan modifikasi. Sebanyak 6,25 g daun kenikir direbus pada suhu 70 dan $100{ }^{\circ} \mathrm{C}$ selama 5 dan 15 menit setelah air mendidih. Pemasakan dengan metode pengukusan, daun kenikir diletakkan pada tray atau dandang pengukus. Proses pengukusan dilakukan pada tekanan atmosfer selama 5 dan 15 menit setelah air mendidih. Sedangkan proses pemanasan dengan microwave, daun kenikir diletakkan dalam wadah kaca dan dipanaskan dengan microwave komersil (tanpa menggunakan air) 450 watt selama 1 dan 3 menit. Daun kenikir setelah perlakuan pengolahan dan sampel segar dikering anginkan. Sampel yang telah cukup kering dihaluskan untuk tahapan selanjutnya.

\section{Ekstraksi Daun Kenikir}

Metode ekstraksi yang digunakan dalam penelitian ini berdasarkan metode Mediani dkk. (2013) yang dimodifikasi. Daun kenikir yang telah kering ditambahkan $25 \mathrm{~mL}$ metanol 100\% (HPLC grade). Kemudian, sampel disonikasi dalam water bath sonicator dengan suhu $30^{\circ} \mathrm{C}$ selama 1 jam. Ekstrak kemudian disentrifugasi dengan kecepatan $10.000 \mathrm{rpm}$, suhu $4^{\circ} \mathrm{C}$, selama 20 menit. Ekstrak dipisahkan dari endapan menggunakan kertas saring dan kemudian disimpan dalam botol amber pada suhu $4^{\circ} \mathrm{C}$ hingga analisis dilakukan.

\section{Analisis Total Senyawa Fenolik}

Total senyawa fenolik (TSF) dianalisis dengan menggunakan metode Folin-Ciocalteu (Yoshimoto dkk., 2002). Untuk analisis, $80 \mu \mathrm{L}$ ekstrak dalam metanol dipipet ke dalam tabung reaksi kemudian dilarutkan dalam akuades sebanyak $2 \mathrm{~mL}$. Sampel kemudian ditambahkan dengan $200 \mu \mathrm{L}$ reagen Folin-Ciocalteu yang sebelumnya telah diencerkan menjadi 0,25 N. Reaksi dibiarkan pada suhu ruang selama 3 menit. Setelah itu, $1 \mathrm{~mL} \mathrm{Na} \mathrm{CO}_{3} 7,5 \%$ ditambahkan pada campuran. Campuran diinkubasi dalam ruang gelap selama 2 jam. Absorbansi kemudian diukur pada panjang gelombang $765 \mathrm{~nm}$ dengan menggunakan spektrofotometer UVVIS, dinyatakan sebagai mg ekuivalen asam galat $/ 100 \mathrm{~g}$ sampel berat basah (mg GAE/100 g sampel BB).

\section{Analisis Aktivitas Antioksidan terhadap 2,2-diphenyl-1-picrylhydrazyl (DPPH)}

Analisis aktivitas antioksidan pada daun kenikir dilakukan dengan menggunakan metode DPPH (Ahmad dkk., 2009) yang dimodifikasi. Modifikasi metode yang digunakan terdapat pada volume ekstrak, volume milli-Q, serta volume DPPH yang digunakan. Penurunan absorbansi dari radikal bebas DPPH dibaca pada panjang gelombang $517 \mathrm{~nm}$. Sebagai kontrol digunakan metanol $100 \%$.

\section{Analisis Senyawa Aktif}

Analisis kadar asam kafeat dan asam ferulat dalam daun kenikir dilakukan berdasarkan metode Sun dkk. (2014) dengan Reversed Phase-Ultra High Performance Liquid Chromatography (RP-UHPLC). Deteksi dan kuantifikasi dilakukan dengan detektor photo diode array (PDA) pada panjang gelombang $300 \mathrm{~nm}$. Pemisahan dilakukan dengan kolom C-18 dengan panjang $\pm 10 \mathrm{~cm}$. Fase gerak terdiri atas asetonitril dan 3\% asam format dalam milique menggunakan sistem gradien. Kecepatan alir eluen sebesar $0,3 \mathrm{~mL} / \mathrm{menit}$. Jumlah asam kafeat dan asam ferulat disajikan dengan satuan $\mathrm{mg} / 100 \mathrm{~g} \mathrm{BB}$ daun kenikir.

\section{Analisis Data}

Rancangan percobaan merupakan Rancangan Acak Lengkap dengan satu faktor yaitu perlakuan proses pengolahan dan respon tiap-tiap analisis yang dilakukan dengan tiga kali ulangan. Data yang dihasilkan akan dianalisis menggunakan analisis varian dengan program SPSS 20, dengan atau $a=0,05$. Jika beda nyata, dilanjutkan dengan uji beda Duncan. Analisis korelasi (r) dilakukan untuk mengetahui hubungan antara kandungan TSF dengan aktivitas antioksidan dengan menggunakan program SPSS 20.

\section{HASIL DAN PEMBAHASAN}

\section{Total Senyawa Fenolik}

Hasil pengujian terhadap kandungan TSF dari ekstrak daun kenikir didapatkan nilai yang bervariasi yaitu 148,29-262,36 mg/100 g BB sebagaimana terlihat pada Tabel 1 . Kandungan TSF tertinggi dimiliki oleh kenikir segar (262,36 mg/100 g BB), kemudian diikuti oleh microwave selama 1 menit $(261,25 \mathrm{mg} / 100 \mathrm{~g} \mathrm{BB})$ dan pengukusan selama 5 menit $(255,16 \mathrm{mg} / 100 \mathrm{~g} \mathrm{BB}$ ). Sedangkan kandungan TSF terendah diperoleh setelah perebusan selama 15 menit (148,29 mg/100 g BB).

Kandungan TSF tertinggi daun segar daun kenikir (262,36 mg GAE/100 g BB) lebih tinggi dari hasil yang diperoleh oleh Andarwulan dkk. (2010) dengan kandungan $152,01 \mathrm{mg} \mathrm{GAE} / 100 \mathrm{~g}$ BB. Proses pemanasan skala rumah tangga dapat menurunkan kandungan TSF bila dibandingkan dengan daun segar. Proses perebusan atau pemanasan dengan microwave 3 menit dapat menurunkan kandungan TSF secara signifikan $(p<0,05)$. Sedangkan proses pengukusan atau pemanasan microwave 1 menit tidak signifikan dalam menurunkan 
Tabel 1. Kandungan TSF daun kenikir

\begin{tabular}{lccc}
\hline No & Perlakuan & $\begin{array}{c}\text { Nilai TSF* } \\
(\text { mg GAE } / 100 \text { mg BB })\end{array}$ & $\begin{array}{c}\text { Penurunan } \\
\text { Nilai TSF }(\%)^{* *}\end{array}$ \\
\hline 1 & Segar & $262,36 \pm 9,31^{\text {a }}$ & - \\
2 & Perebusan $100^{\circ} \mathrm{C}, 5$ menit & $167,12 \pm 2,08^{\text {d }}$ & $36,23 \pm 3,11$ \\
3 & Perebusan $100^{\circ} \mathrm{C}, 15$ menit & $148,29 \pm 6,28^{\mathrm{e}}$ & $43,49 \pm 0,46$ \\
4 & Perebusan $70^{\circ} \mathrm{C}, 5$ menit & $183,29 \pm 4,07^{\mathrm{c}}$ & $30,12 \pm 1,11$ \\
5 & Perebusan $70^{\circ} \mathrm{C}, 15$ menit & $183,12 \pm 2,11^{\mathrm{c}}$ & $30,16 \pm 1,79$ \\
6 & Pengukusan 5 menit & $255,16 \pm 8,84^{\text {a }}$ & $2,68 \pm 4,34$ \\
7 & Pengukusan 15 menit & $251,30 \pm 7,29^{\text {a }}$ & $4,16 \pm 3,51$ \\
9 & Microwave 1 menit & $261,25 \pm 6,51^{\text {a }}$ & $0,40 \pm 1,15$ \\
\hline
\end{tabular}

Keterangan: *Nilai TSF merupakan rerata dari tiga ulangan dengan standar deviasi. Huruf yang berbeda menunujukkan perlakuan yang berbeda signifikan $(p<0,05)$. **Perhitungan persentase perubahan nilai TSF diperoleh merupakan rata-rata tiga ulangan dengan standar deviasi. BB=Berat Basah.

kandungan TSF. Hal ini sesuai dengan penelitian yang dilakukan oleh Sun at al. (2014) yang melakukan pengujian pada daun ubi jalar bahwa proses pengukusan merupakan metode terbaik dalam mempertahankan kandungan TSF dan aktivitas antioksidan. Lebih lanjut Sun dkk. (2014) melaporkan bahwa proses pengukusan pada daun ubi jalar dapat meningkatkan kandungan TSF sebesar 9,44\%; sebaliknya proses perebusan dapat menurunkan kandungan TSF sebesar 30,51 \%.

Penurunan kandungan TSF juga bisa diakibatkan oleh larutnya senyawa fenolik ke dalam air (Chuah dkk., 2008). Poses pengukusan atau pemanasan microwave satu menit tidak menyebabkan perbedaan dibandingkan dengan daun kenikir segar karena tidak kontak langsung dengan air sehingga larutnya senyawa fenolik ke dalam air tidak terjadi. Penurunan kandungan TSF juga dapat dipengaruhi oleh suhu dan waktu proses pemanasan yang dilakukan. Hal ini sesuai dengan laporan Roy dkk. (2007), yang mengindentifikasi pengaruh suhu air $\left(50,75\right.$ dan $100^{\circ} \mathrm{C}$ ) dan waktu pemasakan (10 dan 30 menit) pada TSF daun kol. Hasilnya, terjadi penurunan kandungan TSF dengan naiknya suhu dan lamanya waktu pemasakan yang dilakukan. Penurunan nilai kandungan TSF yang signifikan setelah proses perebusan dan microwave selama tiga menit menunjukkan terjadinya penurunan kadar senyawa-senyawa fenolik pada daun kenikir. Asam fenolik merupakan senyawa yang rentan terhadap kerusakan akibat pemanasan dikarenakan struktur yang sangat terhidroksilasi yang mudah rusak dengan reaksi redoks (Lemos dkk., 2012).

\section{Aktivitas Antioksidan}

Aktivitas antioksidan ditentukan dengan metode penangkapan radikal bebas 2,2-diphenyl-1-picryhidracyl
(DPPH). DPPH adalah radikal bebas stabil yang tidak terdimerisasi dikarenakan delokalisasi elektron bebas pada molekulnya. Delokalisasi juga menyebabkan warna ungu pada cairan DPPH. Selain itu DPPH juga dapat bereaksi dengan atom hidrogen membentuk DPPH tereduksi (DPP Hidrazin) yang stabil dan menyebabkan berkurangnya intensitas warna ungu larutan DPPH hingga berubah warna menjadi kuning pucat (Molyneux, 2004).

Aktivitas antioksidan dari suatu tanaman sangat ditentukan oleh komponen bioaktif yang terdapat pada tanaman. Aktivitas antioksidan ditunjukkan sebagai persen penghambatan, yaitu kemampuan ekstrak untuk menghambat aktivitas senyawa radikal DPPH. Semakin pudarnya warna DPPH setelah direaksikan dengan senyawa atau ekstrak tanaman sebagai indikator semakin tinggi aktivitas senyawa atau komponen

Tabel 2. Aktivitas antioksidan daun kenikir

\begin{tabular}{clc}
\hline No. & \multicolumn{1}{c}{ Perlakuan } & Persentase Penghambatan * \\
\hline 1 & Segar & $91,42 \pm 1,30^{\mathrm{a}}$ \\
2 & Perebusan $100^{\circ} \mathrm{C}, 5$ menit & $73,71 \pm 0,73^{\mathrm{d}}$ \\
3 & Perebusan $100^{\circ} \mathrm{C}, 15$ menit & $50,91 \pm 0,45^{\mathrm{f}}$ \\
4 & Perebusan $70^{\circ} \mathrm{C}, 5$ menit & $80,59 \pm 2,45^{\mathrm{c}}$ \\
5 & Perebusan $70^{\circ} \mathrm{C}, 15$ menit & $68,79 \pm 3,04^{\mathrm{e}}$ \\
6 & Pengukusan 5 menit & $91,90 \pm 1,03^{\mathrm{a}}$ \\
7 & Pengukusan 15 menit & $91,90 \pm 0,56^{\mathrm{a}}$ \\
8 & Microwave 1 menit & $91,45 \pm 1,35^{\mathrm{a}}$ \\
9 & Microwave 3 menit & $88,96 \pm 1,15^{\mathrm{b}}$ \\
\hline
\end{tabular}

*Keterangan: Nilai \% penghambatan merupakan rata-rata dari tiga ulangan dengan standar deviasi. Huruf yang berbeda menunjukkan perlakuan yang berbeda signifikan $(p<0,05)$. 
antioksidan yang terdapat pada ekstrak tanaman (Benabadji dkk., 2004).

Hasil analisis aktivitas antioksidan disajikan pada Tabel 2. Pemanasan skala rumah tangga dengan perebusan atau pemanasan microwave tiga menit dapat menurunkan persen penghambatan secara signifikan $(p<0,05)$, sedangkan pemanasan dengan pengukusan atau microwave satu menit tidak memberikan pengaruh secara signifikan. Hasil pada Tabel 2 sesuai dengan kandungan TSF yang disajikan pada Tabel 1 . Kandungan TSF pada daun kenikir memiliki peran sebagai antioksidan, sehingga, proses pengolahan dapat mempengaruhi kandungan TSF dan dapat mempengaruhi nilai \% penghambatan.

Efek pemanasan skala rumah tangga terhadap nilai TSF dan aktivitas antioksidan daun kenikir dipengaruhi oleh berbagai faktor seperti proses selama pemanasan, suhu dan waktu pemanasan, pelarut yang digunakan saat ekstraksi, dan medium pemanasan (Galor dkk., 2008). Penurunan kandungan TSF pada semua proses perebusan atau microwave selama tiga menit diduga disebabkan oleh kerusakan senyawa fenolik akibat proses pemasakan (Xu dkk., 2007). Pemanasan microwave selama 3 menit memberikan penurunan yang lebih besar jika dibandingkan dengan pemanasan microwaveselama satu menit. Hal ini diduga karena waktu proses yang lebih lama sehingga memberikan kerusakan senyawa fenolik yang lebih besar. Senyawa fenolik merupakan senyawa yang sensitif terhadap pemanasan. Degradasi dari senyawa fenolik akibat pemanasan disebabkan oleh meningkatnya reaksi oksidasi dan pemecahan ikatan kovalen akibat pemanasan (Zhang dkk., 2012). Pemanasan microwave selama tiga menit daun menjadi kering dan rusaknya komponen bioaktif sehingga terjadi penurunan kandungan TSF dan aktvitas antioksidan.

\section{Korelasi antara TPC dan Aktivitas Antioksidan}

Hasil analisis regresi linear hubungan antara kandungan TSF dan persen penghambatan daun kenikir disajikan pada Gambar 1. Hasil analisis menunjukkan bahwa terdapat korelasi positif yang sangat kuat $(r>0,90)$ antara kandungan TSF dengan persen penghambatan dengan nilai koefisien korelasi sebesar $r=0,904$. Hal ini menunjukkan bahwa aktivitas antioksidan daun kenikir dipengaruhi oleh kandungan TSF. Senyawa fenolik dapat berperan sebagai antiokisan dengan mendonasikan atom hidrogen yang menyebabkan peluruhan warna ungu DPPH menjadi kuning yang diukur pada panjang gelombang $517 \mathrm{~nm}$. Semakin tinggi kandungan TSF akan menghasilkan aktivitas antioksidan yang tinggi pula.

Beberapa studi sebelumnya telah melaporkan hubungan antara aktivitas antioksidan dan kandungan TSF, di mana hasilnya menyatakan bahwa terdapat korelasi positif antara aktivitas antioksidan dan kandungan TSF. Lai \& Lim (2011) melaporkan bahwa korelasi yang kuat antara nilai TPC dan persen penghambatan pada ekstrak tanaman pakis sebesar $r=0,953$.

\section{Senyawa Aktif Daun Kenikir}

Hasil analisis HPLC daun kenikir segar memiliki kadar asam kafeat dan asam ferulat yang tinggi $(14,29$ dan $13,55 \mathrm{mg} / 100 \mathrm{~g} \mathrm{BB}$ ). Proses pemanasan skala rumah tangga memberikan dampak yang berbeda-beda terhadap kandungan asam kafeat dan asam ferulat. Perebusan menyebabkan kehilangan asam kafeat sebesar 59,66-92,47\% dan kehilangan asam ferulat sebesar 31,4-57,32\%. Akan tetapi, proses pengukusan memberikan peningkatan sebesar 6,99-58,94\%. Pemanasan dengan microwave selama satu menit memberikan peningkatan kadar asam kafeat sebesar

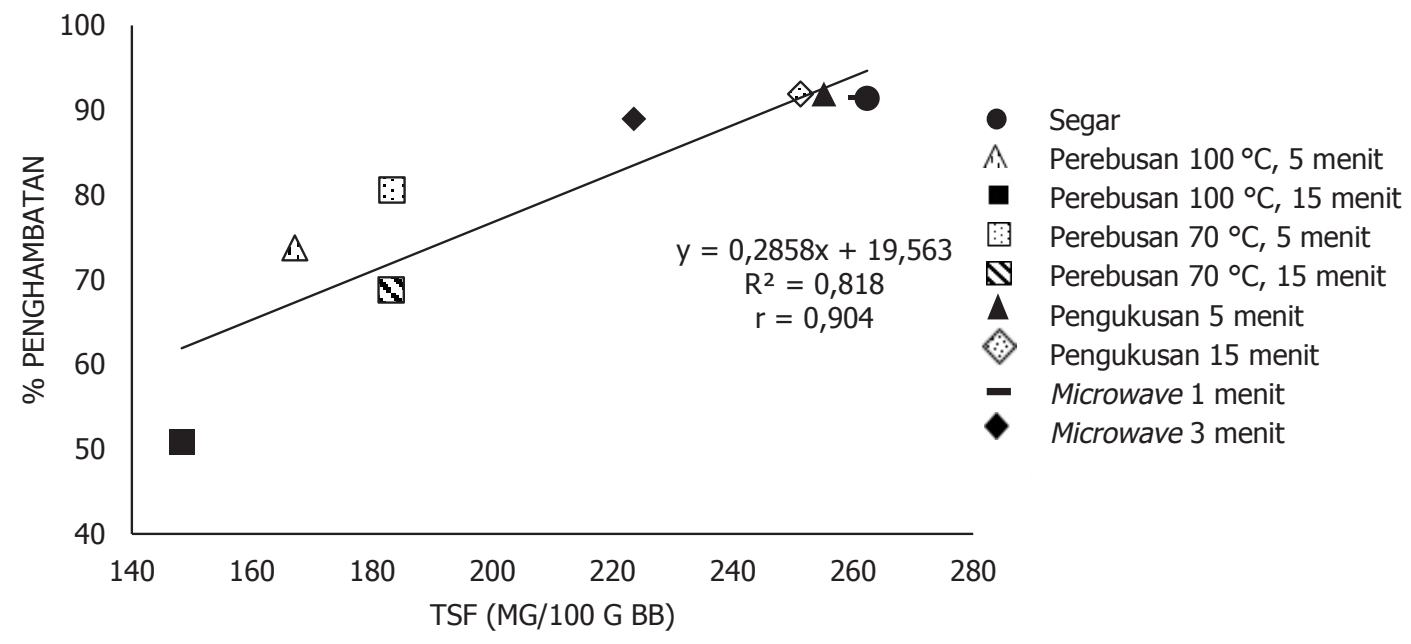

Gambar 1. Grafik hubungan kandungan TSF dengan aktivitas antioksidan (\% penghambatan) 
$72,89 \%$ namun memberikan penurunan sebesar $8,68 \%$ pada asam ferulat. Pemanasan microwave selama 3 menit memberikan penurunan $11,25 \%$ pada asam kafeat namun memberikan peningkatan pada asam ferulat hingga $386,08 \%$. Kandungan asam kafeat dan asam ferulat daun kenikir dapat dilihat pada Tabel 3.

Studi sebelumnya menyatakan bahwa senyawasenyawa fenolik yang terdapat pada daun kenikir segar adalah quercetin $(4,5 \mathrm{mg} / 100 \mathrm{~g} \mathrm{BB})$, kaempferol $(0,9$ $\mathrm{mg} / 100 \mathrm{~g} \mathrm{BB})$, asam klorogenat $(4,54 \mathrm{mg} / 100 \mathrm{~g} \mathrm{BB})$, asam kafeat $(3,64 \mathrm{mg} / 100 \mathrm{~g} \mathrm{BB})$, dan asam ferulat $(3,14$ $\mathrm{mg} / 100 \mathrm{~g}$ BS) (Andarwulan dkk.,2010; Andarwulan dkk., 2012). Kandungan asam kafeat dan ferulat yang diperoleh dalam penelitian ini lebih tinggi dari penelitian sebelumnya.

Pengaruh pemanasan terhadap senyawa fenolik dapat berbeda-beda dikarenakan matriks pangan yang berbeda-beda pada tiap-tiap bahan pangan (Irina dan Mohamed, 2012). Selain itu, struktur senyawa fenolik juga dapat berpengaruh terhadap kestabilan senyawa fenolik dari pemanasan, misalnya rutin memiliki kestabilan yang lebih baik terhadap pemanasan dibandingkan bentuk aglikonnya yaitu quercetin (Buchner dkk., 2006).

Beberapa studi lain yang mengidentifikasi pengaruh proses pemanasan terhadap senyawa fenolik pada bahan atau produk pangan. Rutin (quercetin-3-Orutinosida) pada buckwheat (soba) yang telah digiling dilaporkan lebih stabil terhadap pemanasan selama proses pemanggangan pada suhu $160{ }^{\circ} \mathrm{C}$ selama 30 menit (Zielinski dkk., 2009). Studi lain menyatakan bahwa perebusan dapat menyebabkan kehilangan quercetin dan kaempferol pada kacang Brazil (Ranilla dkk., 2009). Asam fenolat seperti asam klorogenat

Tabel 3. Kandungan asam kafeat dan asam ferulat daun kenikir

\begin{tabular}{lcc}
\hline \multicolumn{1}{c}{ Perlakuan } & $\begin{array}{c}\text { Asam kafeat } \\
(\mathrm{mg} / 100 \mathrm{~g} \mathrm{BB})\end{array}$ & $\begin{array}{c}\text { Asam ferulat } \\
(\mathrm{mg} / 100 \mathrm{~g} \mathrm{BB})\end{array}$ \\
\hline Segar & 14,29 & 13,56 \\
Perebusan $100^{\circ} \mathrm{C}$, 5 menit & 1,08 & 5,79 \\
Perebusan $100^{\circ} \mathrm{C}, 15$ menit & 1,61 & 5,34 \\
Perebusan $75^{\circ} \mathrm{C}, 5$ menit & 0,97 & 4,72 \\
Perebusan $75^{\circ} \mathrm{C}, 15$ menit & 5,77 & 9,30 \\
Pengukusan 5 menit & 22,72 & 14,50 \\
Pengukusan 15 menit & 20,94 & 17,24 \\
Microwave 1 menit & 24,71 & 12,35 \\
Microwave 3 menit & 12,68 & 65,89 \\
\hline
\end{tabular}

Keterangan: BB (Berat Basah) dilaporkan menurun sebesar 37,69\% setelah mengalami proses pemanasan dengan autoclave $121^{\circ} \mathrm{C}$ selama 10 menit (Huber dkk., 2014). Begitu juga pada studi Lemos dkk. (2012) yang melaporkan bahwa proses roasting menyebabkan penurunan asam kafeat, asam ferulat, asam hidroksi benzoate, dan katekin yang signifikan pada kacang baru (Dipteryx alata Vog.) Akan tetapi, studi oleh Xu dkk. (2007) melaporkan bahwa proses pemanasan pada suhu $120{ }^{\circ} \mathrm{C}$ selama 30,60 , dan 90 menit justru meningkatkan asam ferulat dan asam p-koumarat secara signifikan pada kulit Citrus paradisi Changshanhuyou.

\section{KESIMPULAN}

Proses pemanasan skala rumah tangga dengan pengukusan atau pemanasan microwave selama satu menit mampu mempertahankan kandungan TSF dan aktivitas antioksidan daun kenikir. Semua proses perebusan dan pemanasan microwave tiga menit dapat menurunkan secara signifikan $(p<0,05)$ kandungan TSF dan aktivitas antioksidan daun kenikir. Analisis dengan RP-UHPLC menunjukkan bahwa proses perebusan dapat menurunkan kandungan asam kafeat dan asam ferulat daun kenikir, sebaliknya dengan pengukusan atau pemanasan microwave dapat meningkatkan kedua senyawa tersebut. Terdapat hubungan yang kuat antara kandungan TSF dengan aktivitas antioksidan ekstrak daun kenikir. Semakin tinggi kandungan TSF, semakin tinggi pula aktivitas antioksidannya.

\section{UCAPAN TERIMA KASIH}

Penulis menyampaikan penghargaan dan terima kasih atas dana penelitian yang diberikan oleh Lembaga Penelitian dan Pengembangan (LPP) Universitas Bakrie.

\section{KONFLIK KEPENTINGAN}

Penulis menyatakan tidak ada konflik kepentingan terkait dengan naskah ini.

\section{DAFTAR PUSTAKA}

Ajaykumar, T.V., Anandarajagopal, K., Sunildon, J.A.J., Arshad, A., Jainaf, R.A.M., \& Venkateshan, N. 2012. Antiinflammatory activity of Cosmos caudatus. International Journal of Universal Pharmacy and Bio sciences, 2, 4048.

Ahmad, I. M., Abdalla, M. Y., Mustafa, N. H., Qnais, E. Y., \& Abdullah, F. A. (2009). Datura aqueous leaf extract 
enhances cytotoxicity via metabolic oxidative stress on different human cancer cells. Jordan Journal of Biological Sciences, 2, 9-14.

Andarwulan, N., Ratna B., Diny A. S., Bradley B., \& Hanny W. (2010). Flavonoid contenct and antioxidant activity of vegetables from indonesia. Food Chemistry, 121, 12311235. http://doi: 10.1016/j.foodchem.2010.01.033

Andarwulan, N., Dewi K., Riza A. A., Hardianzah R., Anna V. R., \& Bradley B. (2012). Polyphenols, carotenoids, and ascorbic acid in underutilized medicinal vegetable. Journal of Functional Food, 4, 339-347. https://doi. org/10.1016/j.jff.2012.01.003

Benabadji, S.H., Wen, R., Zheng, J.B., Dong, X. C., \& Yuan, S.G. 2004. Anticarcinogenis and antioxidant activity of diindolylmenthane derivatives. Acta Pharmacology Sinica, 25, 666-671.

Birben, E., Sahiner, U. M., Sackesen, C., Erzurum, S., Kalayci, O. (2012). Oxidative stress and antioxidant defense. World Allergy Organization Journal, 5, 9-19. http://doi: 10.1097/WOX.0b013e3182439613

Bodeker, G. (2009). Health and Beauty from the Rainforest: Malaysian Traditions of Ramuan. Kuala lumpur: Didier Millet.

Buchner, N., Angelika K., Sascha R., \& Lothar, W. K. (2006). Effect of thermal processing on flavonols rutin and quercetin. Rapid Communications in Mass Spectrometry, 20, 3229-3235. https://doi.org/10.1002/rcm.2720

Chuah, A. M., Ya-Chi L., Tomoko Y., Hitoshi T., Li-Jun Y., \& Teruyoshi M. (2008). Effect of cooking on the antioxidant properties of coloured peppers. Food Chemistry, 50, 3010-3014. https://doi.org/10.1016/j. foodchem.2008.03.022

Galor, S. W., Ka W. W., \& Iris F. F. B. (2008). The effect of cooking on brassica vegetable. Food Chemistry, 110, 706-710. https://doi.org/10.1016/j.foodchem.2008.02.056

Huber, K., Priscila B., Eloa B. B., \& Solange G. C-b. (2014). Effect of thermal processing and maceration on the antioxidant activity of white beans. Plos One, 9, 1-8. https://doi: 10.1371/journal.pone.0099325

Girgin, N., \& El, S.N. 2015. Effects of cooking on in vitro sinigrin bioaccessibility, total phenols, antioxidant and antimutagenic activity of cauliflower (Brassica oleraceae L. var. Botrytis). Journal of Food Composition and Analysis, 37, 19-127. https://doi.org/10.1016/j. jfca.2014.04.013

Irina, I., and Mohamed, G. (2012). Biological activities and effects of food processing on flavonoids as phenolic antioxidants. In Petre, M (Eds.), Advances in applied biotechnology (pp. 101-124). Intech Open Access. https://doi: $10.5772 / 30690$

Lai, H.Y., and Lim, Y.Y. (2011). Evaluation of antioxidant activities of methanolic extracts of selected ferns in
Malaysia. International Journal of Environmental Science and Development, 2 (6), 442-447. DOI: 10.18178/IJESD

Lemos, M. R. B., Siquera, E.M.A., Arruda, S.F., Zambiazi, R.C. (2012). The effect of roasting on the phenolic compounds and antioxidant potential of baru nuts (Dipteryx alata Vog.). Food Research International, 48 (2), 592-597. https://doi.org/10.1016/j.foodres.2012.05.027

Miglio, C., Emma C., Attilo V., Vincenzo F., \& Nicoletta P. (2008). Effects of different cooking methods on nutritional and physicochemical characteristics of selected vegetables. Journal of Agricultural and Food Chemistry, 56, 139-147. https://pubs.acs.org/doi/abs/10.1021/jf072304b

Mediani, A., Faridah A., Alfi K., \& Chin P. T. (2013). Cosmos caudatus as a potential source of polyphenolic compounds: optimisation of oven drying conditions and characterisation of its functional properties. Moleculs, 18, 10452-10464. https://doi.org/10.3390/ molecules180910452

Molyneux, P. (2004). The use of the stable free radical diphenylpicryhydrazyl (DDPH) for estimating antioxidant activity. Journal science and technology, 26(2), 209-211.

Mustafa, R.A., Abdul, H. A., Mohamed, S., \& Bakar, F. A. (2010). Total phenolic compounds, flavonoids and radical scavenging activity of 21 selected tropical plants. Journal of Food Science, 75, c28-c35. https://doi. org/10.1111/j.1750-3841.2009.01401.x

Ranilla, L. G., Genovese, M. I., \& Lajolo, F. M. (2009). Effect of different cooking conditions on phenolic compounds and antioxidant capacity of some selected Brazilian bean (Phaselous vulgaris I.) Cultivars. Journal of Agricultural and Food Chemistry, 57, 5734-5742. https://dx.doi. org/10.1021/jf900527v

Roy, M. K., Takenaka, M., Isobe, S., \& Tsushida, T. (2006). Antioxidant potential, anti-proliferative activities, and phenolic content in water-soluble fractions of some commonly consumed vegetables: effects of thermal treatment. Food Chemistry, 103, 106-114. https://doi. org/10.1016/j.foodchem.2006.08.002

Sun, H., Mu, T., Xi, L., \& Song, Z. (2014). Effect of domestic cooking methods on polyphenols and antioxidant activity of sweet potato leaves. Journal of Agricultural and Food Chemistry, 62, 8982-8989. https://pubs.acs. org/doi/10.1021/jf502328d

Xu, G., Ye, X., Chen, J., \& Liu, D. (2007). Effect of heat treatment on phenolic compounds and antioxidant capacity of citrus peel extract. Journal of Agricultural and Food Chemistry, 55, 330-335. https://pubs.acs.org/ doi/abs/10.1021/jf062517I

Yoshimoto M., Yahara, Okuno S., Islam M., Ishiguro K., \& Yamakawa O. (2002). Antimutagenecity of mono-, di, and tricaffeoylquinic acid derivatives isolated from sweet potato (Ipomea batatas) leaf. Bioscience Biotechnology 
Biochemistry, 66, 2336-2341. https://doi.org/10.1271/ bbb.66.2336

Zhang, L., Zhou, J., Liu, H., Khan, M. A., Huang, K., \& Gu, Z. (2012). Composition of anhocyanins in blackberry juice and their thermal degradation in relation to antioxidant activity. European Food Research Technology, 235, 637645.
Zielinski, H., Mishalska, A., Amigo-Benavent, M., Del Castillo, M. D. \& Piskula, M. K. (2009). Changes in protein quality and antioxidant properties of buckwheat seeds and groats induced by roasting. Journal of Agricultural and Food Chemistry, Vol.57, 4771-4777. https://pubs.acs. org/doi/abs/10.1021/jf900313e 